\title{
Cyclic AMP-Responsive Element-Binding Protein 3
}

National Cancer Institute

\section{Source}

National Cancer Institute. Cyclic AMP-Responsive Element-Binding Protein 3. NCI

Thesaurus. Code C38539.

Cyclic AMP-responsive element-binding protein 3 (395 aa, 44 kDa) is encoded by the human CREB3 gene. This protein is involved in the modulation of transcription downstream of regulated intramembrane proteolysis. 